\title{
Methionine ligand interaction in a blue copper protein characterized by site- selective infrared spectroscopy
}

\author{
Amanda L. Le Sueur, Richard N. Schaugaard, Mu-Hyun Baik, Megan C. Thielges*
}

\section{Table of Contents.}

Construction of Pc expression plasmid $\quad$ S1

$\begin{array}{ll}\text { Expression and purification of Pc (Figure S1) } & \text { S1 }\end{array}$

$\begin{array}{ll}\text { Preparation of ApoPc } & \text { S2 }\end{array}$

Preparation of Co(II)Pc and Zn(II)Pc (Figure S2) $\quad$ S2

$\begin{array}{ll}\text { Preparation of unfolded Pc } & \text { S3 }\end{array}$

$\begin{array}{ll}\text { Expression and purification of cyt } f & \text { S3 }\end{array}$

Circular dichroism spectroscopy for Pc variants (Figure S3 and S4) $\quad$ S4

Sample preparation for FT IR spectroscopy (Figures S5 - S7, Table S1) S5

Calculations (Figure S8-S11, Tables S2 and S3) $\quad$ S8

References $\quad$ S11

Construction of Pc expression plasmid. The plasmid pEAP containing the petE gene encoding for plastocyanin (Pc) in Nostoc PCC7119 constructed by Dr. Miguel A. De la Rosa (University of Seville) ${ }^{1}$ was provided by Dr. Marcellus Ubbink (Leiden University). The leader sequence encoding the first 34 amino acids was removed to achieve cytoplasmic expression according to literature procedures. ${ }^{2}$ The truncated gene was subcloned as a NdeI-XhoI restriction fragment into vector pET28a. To ensure expression of Pc containing a unique methionine at position 97 ( $d_{3} \mathrm{Met} 97 \mathrm{Pc}$ ), the following additional modifications to the Pc sequence were introduced. Two alanine codons were introduced after the initiator methionine codon and the Pc was coexpressed with methionine aminopeptidase (using plasmid pMetAP-GTG-21a ${ }^{3}$ ) to ensure removal of the initiator methionine residue. In addition, the only other methionine of Pc, Met66, was substituted with leucine using site-directed mutagenesis. We use the same amino acid numbering for the modified Pc as derived from PDB entry 1TU2 for Nostoc Pc and exclude the initial methionine and the non-native precursor sequence 'MAA-' for clarity when comparing to literature numbering. The integrity of the final construct (pSS01-MAAE-M66L, hereafter referred to as Pc) was verified by sequencing.

Expression and purification of Pc. Six $1 \mathrm{~L}$ cultures were grown at $37{ }^{\circ} \mathrm{C}$ in the presence of 100 $\mu \mathrm{g} / \mathrm{mL}$ ampicillin and $50 \mu \mathrm{g} / \mathrm{mL}$ kanamycin with $250 \mathrm{rpm}$ shaking until $\mathrm{OD}_{600}$ reached 0.6 . The expression of the Pc gene was induced with $1 \mathrm{mM}$ isopropyl $\beta$-D-1-thiogalactopyranoside (IPTG) for 20 hours at $30{ }^{\circ} \mathrm{C}$ after which the cells were harvested by centrifugation at $6400 \mathrm{x}$ g for 20 min. The pellet was resuspended in $1 \mathrm{mM}$ sodium phosphate $(\mathrm{NaPi}) \mathrm{pH}$ 6.8, $1 \mathrm{mM}$ PMSF, 250 $\mu \mathrm{M} \mathrm{CuSO}_{4}$, and supplemented with $0.2 \mathrm{mg} / \mathrm{mL}$ DNase I. The cells were lysed by sonication and centrifuged at $12,000 \mathrm{x}$ g for $50 \mathrm{~min}$. The supernatant was dialyzed extensively in $1 \mathrm{mM} \mathrm{NaPi}$, $\mathrm{pH} 6.8,250 \mu \mathrm{M} \mathrm{CuSO}_{4}$, and the dialyzed sample was then clarified by centrifugation at $12,000 \mathrm{x}$ 
$\mathrm{g}$ for 40 minutes. The supernatant was applied to a $\mathrm{S}$ cellulose cation exchange column (BioRad) equilibrated with $1 \mathrm{mM} \mathrm{NaPi}, \mathrm{pH} 6.8$ and eluted using a linear gradient of $1-200 \mathrm{mM}$ $\mathrm{NaPi}$, pH 6.8. Eluting fractions containing Pc by visible spectroscopy were collected, concentrated, and applied to a size exclusion column (Sephacryl S-100 HR, GE Healthcare Life Sciences, $125 \mathrm{~mL})$. The concentration of the purified $\mathrm{Pc}\left(\mathrm{A}_{280 / 597}<1.5\right)$ was determined by visible spectroscopy $\left(\varepsilon_{597}=4.5 \mathrm{mM}^{-1} \mathrm{~cm}^{-1}\right){ }^{4}$ MALDI-TOF: $11227.72 \mathrm{~m} / z$, (Figure S1) Calculated: $11358.9 \mathrm{~m} / \mathrm{z}-$ Met $=11227.8 \mathrm{~m} / \mathrm{z}$ ). The protein yield was approximately $17.5 \mathrm{mg}$ per $1 \mathrm{~L}$ of culture. The Pc was brought to $25 \%$ glycerol, flash frozen in liquid $\mathrm{N}_{2}$, and stored at $80{ }^{\circ} \mathrm{C}$.

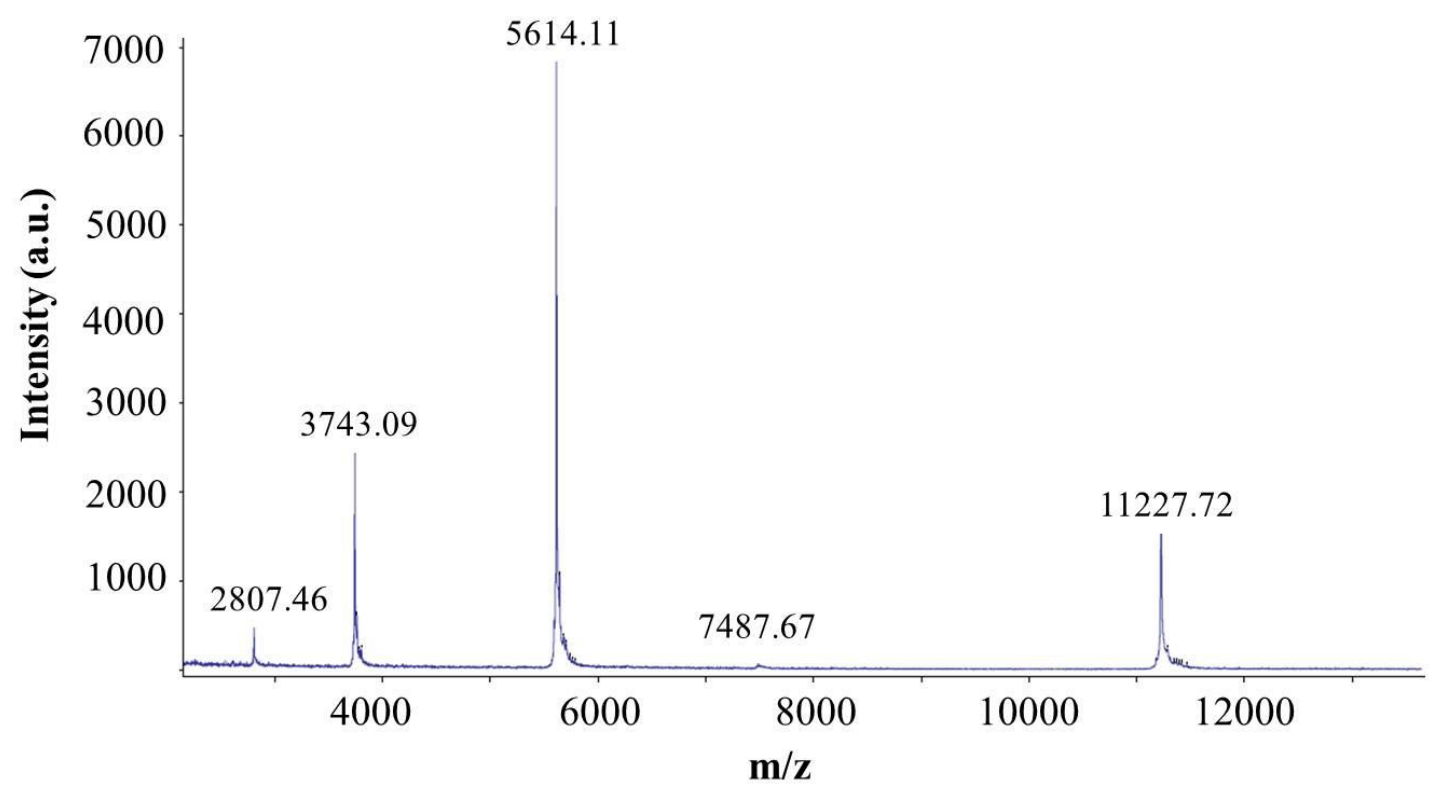

Figure S1. Mass spectrum of expressed MAAE-M67L Pc. MALDI-TOF: 11227.72 m/z

Preparation of ApoPc. Frozen stocks of unlabeled and $d_{3}$ Met97 Pc were dialyzed in $300 \mathrm{mM}$ Tris-Cl, $\mathrm{pH} 7,1 \mathrm{M} \mathrm{NaCl}$ and concentrated to $\sim 2 \mathrm{mM}$. An equal volume of Tris-Cl, $\mathrm{pH} 7,1 \mathrm{M}$ $\mathrm{NaCl}, 50 \mathrm{mM} \mathrm{KCN}$ was then added to the protein solution resulting in the displacement of the $\mathrm{Cu}$ ion from the Pc active site. ${ }^{5}$ The removal of the copper ion by $\mathrm{KCN}$ to form the apoprotein (ApoPc) was complete immediately after 45 minutes as indicated by the change in the protein solution to become colorless and the absence of the $597 \mathrm{~nm}$ absorbance band indicative of the $\mathrm{Cu}$-containing Pc (Figure S2). The protein solution was then equilibrated back into Tris-Cl, $\mathrm{pH}$ $7,1 \mathrm{M} \mathrm{NaCl}$ using 5 cycles of concentration and dilution. Preparation of ApoPc in $300 \mathrm{mM}$ Tris$\mathrm{Cl}, \mathrm{pH} 7,500 \mathrm{mM} \mathrm{NaCl}$ was prepared identically as above but with the substitution of the buffer solution containing the lower $\mathrm{NaCl}$ concentration.

Preparation of Co-substituted Pc (Co(II)Pc) and Zn-substituted Pc ( $\mathrm{Zn}$ (II)Pc). To form unlabeled and $d_{3} \mathrm{Met} 97$ labeled $\mathrm{Co}(\mathrm{II}) \mathrm{Pc}$, ten equivalents of $\mathrm{CoCl}_{2}$ in Tris-Cl, pH 7, $1 \mathrm{M} \mathrm{NaCl}$ 
was added to both unlabeled and $d_{3}$ Met97 labeled ApoPc and thoroughly mixed. After three hours at $4^{\circ} \mathrm{C}$, the uptake of $\mathrm{Co}(\mathrm{II})$ into $\mathrm{Pc}$ was complete as indicated by the appearance of absorbance bands at 330, 384, 507 and $657 \mathrm{~nm}$ in the visible spectrum (Figure S2). ${ }^{6}$ Excess $\mathrm{CoCl}_{2}$ was removed by dialysis in Tris-Cl, $\mathrm{pH} \mathrm{7,1} \mathrm{M} \mathrm{NaCl}$. The concentration of Co(II)Pc was determined using the molar extinction coefficient $\left(2800 \mathrm{M}^{-1} \mathrm{~cm}^{-1}\right)$ for the $330 \mathrm{~nm}$ band. $\mathrm{Cu}$ (II)Pc reconstituted from $\mathrm{Co}(\mathrm{II}) \mathrm{Pc}$ was formed from the addition of five equivalents of $\mathrm{CuSO}_{4}$ to $\mathrm{Co}(\mathrm{II}) \mathrm{Pc}$. The fast uptake of $\mathrm{Cu}$ to form $\mathrm{Cu}(\mathrm{II}) \mathrm{Pc}$ was complete in less than 5 minutes and verified by the presence of the $597 \mathrm{~nm}$ charge transfer band (Table S1, Figure S7). Unlabeled and $d_{3}$ Met97 labeled $\mathrm{Zn}$ (II)Pc were expressed as described above for $\mathrm{Cu}(\mathrm{II}) \mathrm{Pc}$ but with substitution of $\mathrm{ZnSO}_{4}$ for $\mathrm{CuSO}_{4}$ in all steps of expression and purification. The replacement of $\mathrm{Cu}$ with $\mathrm{Zn}$ was verified by the absence of the $597 \mathrm{~nm}$ charge transfer absorbance band in its visible spectrum. ${ }^{7}$

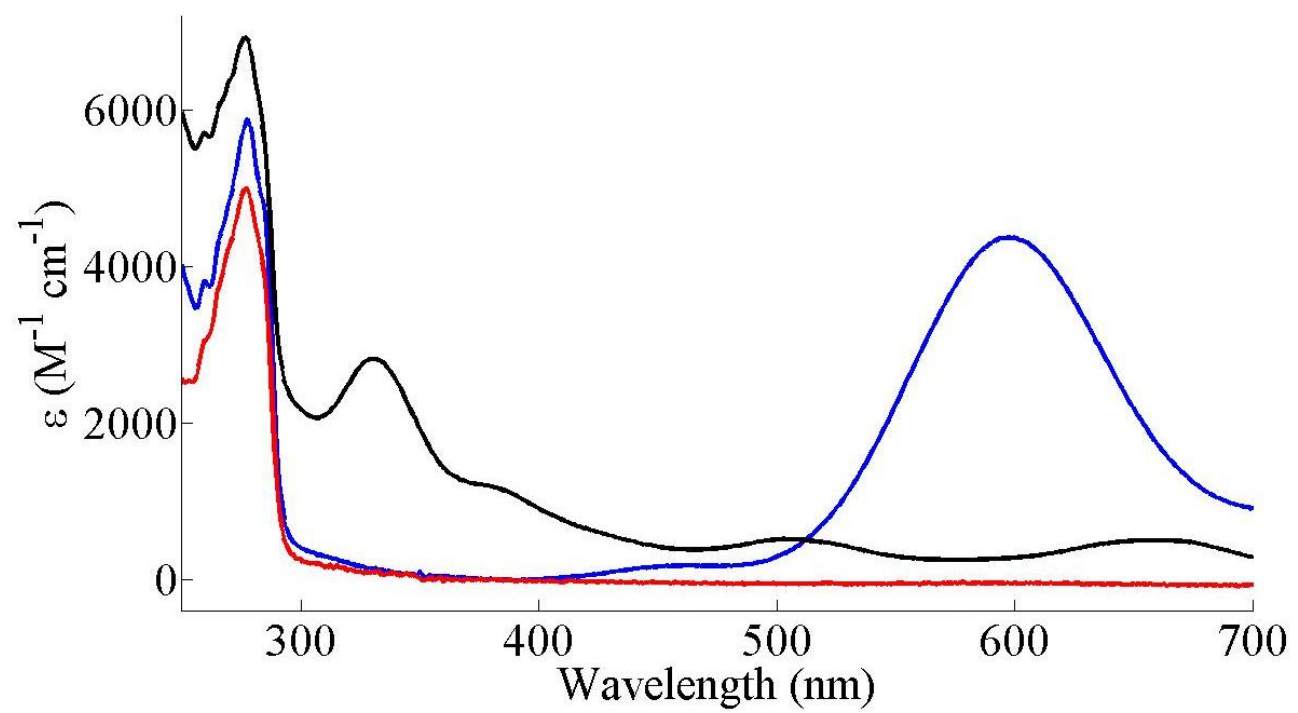

Figure S2. Absorbance data of $\mathrm{Cu}(\mathrm{II}) \mathrm{Pc}$ (blue), $\mathrm{Co}(\mathrm{II}) \mathrm{Pc}$ (black) and ApoPc (red) normalized by concentration.

Preparation of unfolded Pc. Unlabeled and $d_{3}$ Met97 labeled Pc in Tris-Cl, $\mathrm{pH} 7,1 \mathrm{M} \mathrm{NaCl}$ was unfolded by the addition of equal volume of $6 \mathrm{M}$ guanidinium chloride. The solution was mixed and allowed to equilibrate on ice for one hour until the protein solution turned colorless indicating a loss of the $\mathrm{Cu}$ ion from the protein structure due to the unfolding process. The unfolded sample was then equilibrated back into Tris-Cl buffer, $\mathrm{pH} 7,1 \mathrm{M} \mathrm{NaCl}$ by concentration and dilution.

Expression and purification of cyt $f$. The plasmid (pEAF-wt) containing the gene coding for the soluble domain (residues 1- 254) of Nostoc sp. PCC7119 was constructed by Dr. Miguel A. De la Rosa (University of Seville) and provided by Dr. Marcellus Ubbink (Leiden University). pEAF-wt was co-transformed into DH5- $\alpha$ with pEC86, containing a c-type cytochrome 
maturation cassette. ${ }^{8}$ The freshly transformed cells were grown in LB broth supplemented with ampicillin $(100 \mu \mathrm{g} / \mathrm{mL})$, chloramphenicol $(30 \mu \mathrm{g} / \mathrm{mL})$ and ammonium iron (III) citrate $\left(\mathrm{Fe}\left(\mathrm{NH}_{4}\right)_{3}\right.$ citrate, $10 \mathrm{mg} / 14 \mathrm{~mL}$ ) at $25^{\circ} \mathrm{C}, 150 \mathrm{rpm}$ shaking until $\mathrm{OD}_{600}$ reached 0.8. Expression was induced by addition of $1 \mathrm{mM}$ IPTG. At this time, $0.5 \mathrm{mM} \delta$-aminolevulinic acid was also added to ensure sufficient heme production. After 40 hours at $25{ }^{\circ} \mathrm{C}$ with $150 \mathrm{rpm}$ shaking, the cells were harvested by centrifugation at $6400 \mathrm{x}$ g for 20 minutes.

The cells were resuspended in $5 \mathrm{mM}$ Tris-Cl, $\mathrm{pH} 8.2$ and lysed using three freeze-thaw cycles in liquid nitrogen and water. The lysate was centrifuged at 12,000 x g for $50 \mathrm{~min}$. The pellet was resuspended in the same buffer and again lysed using two freeze-thaw cycles. The supernatant was treated with DNase I before dialysis into $5 \mathrm{mM}$ Tris-Cl, $\mathrm{pH}$ 8.2. The cyt $f$ was purified using 0-500 $\mathrm{mM} \mathrm{NaCl}$ gradient elution from a DEAE column (Bio-Rad) in $5 \mathrm{mM}$ Tris-Cl, $\mathrm{pH} \mathrm{8.2,}$ followed by a Q column (Bio-Rad) in $5 \mathrm{mM}$ MES buffer, $\mathrm{pH}$ 6. Additional purification was performed by passage over a Sephacryl S-100 HR gel filtration column (GE Healthcare Life Sciences, $125 \mathrm{~mL})$. Purified cyt $f\left(\mathrm{~A}_{280 / 556}<1.5\right)$ was concentrated, brought to $25 \%$ glycerol, flash-frozen in liquid $\mathrm{N}_{2}$ and stored at $-80{ }^{\circ} \mathrm{C}$. The concentration of cyt $f$ was determined by absorbance spectroscopy using $\varepsilon_{556}=31.5 \mathrm{mM}^{-1} \mathrm{~cm}^{-1} .{ }^{9}$ MALDI-TOF: $27840.94 \mathrm{~m} / \mathrm{z}$, (Calculated: $27222.4 \mathrm{~m} / \mathrm{z}+$ heme $=27838.89$ ). The protein yield was approximately $0.4 \mathrm{mg}$ per 1 L of culture.

Circular dichroism spectroscopy of Pc variants. Spectra of Pc variants were taken to assess the secondary structure in solution. All protein data was recorded in $300 \mathrm{mM}$ Tris-Cl, $\mathrm{pH} \mathrm{7,1M}$ $\mathrm{NaCl}$ in a $1 \mathrm{~mm}$ cuvette. An average of five scans was acquired and background subtracted using a spectrum of Tris-Cl. (Figures S3 and S4)

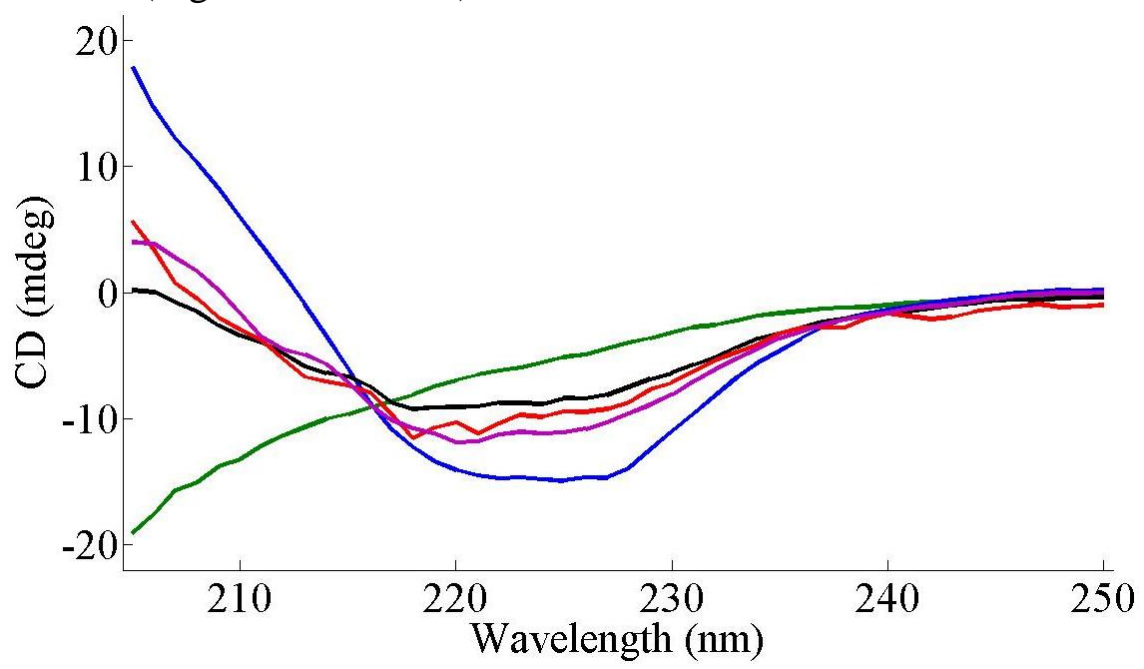

Figure S3. Circular dichroism spectra of $\mathrm{Cu}(\mathrm{II}) \mathrm{Pc}$ (blue), $\mathrm{Zn}$ (II)Pc (red), $\mathrm{Co}$ (II)Pc (purple), ApoPc (black) and unfolded Pc (green). All spectra were normalized by concentration. 


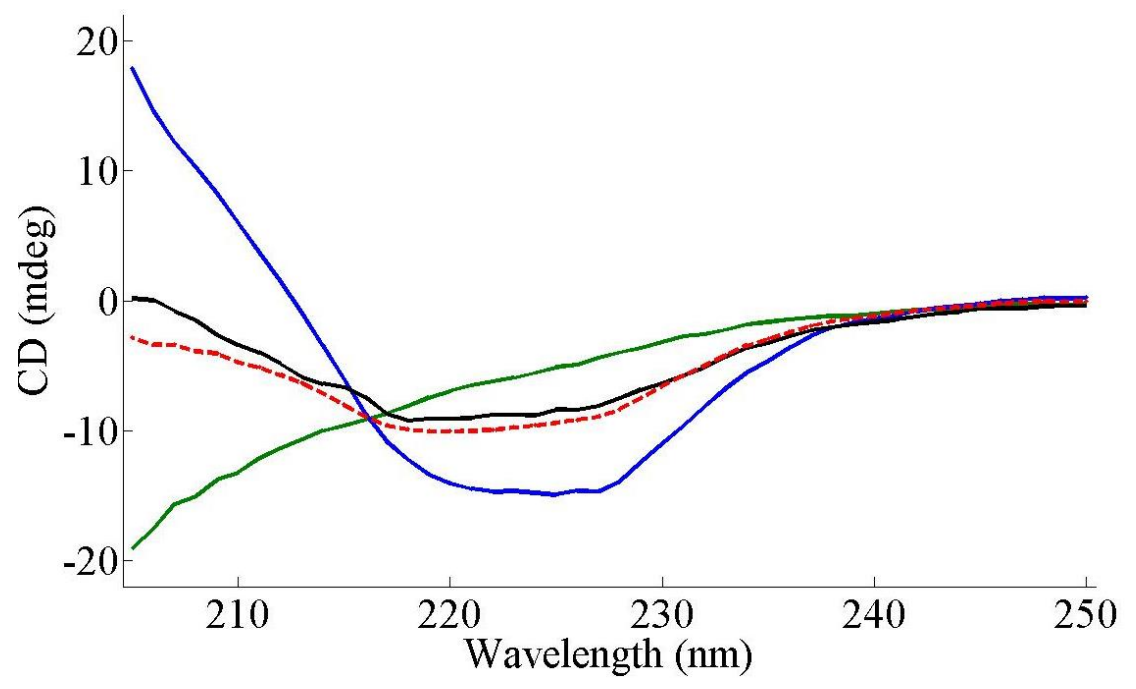

Figure S4. Circular dichroism spectra of $\mathrm{Cu}(\mathrm{II}) \mathrm{Pc}$ (blue), ApoPc (black), unfolded Pc (green) normalized by concentration as well as a linear combination of $44 \% \mathrm{Cu}(\mathrm{II}) \mathrm{Pc}$ and $56 \%$ unfolded Pc to model the ApoPc (red dash).

Sample preparation for FT IR spectroscopy. The Pc variants, $\mathrm{Cu}(\mathrm{I}) \mathrm{Pc}, \mathrm{Cu}(\mathrm{II}) \mathrm{Pc}, \mathrm{Co}(\mathrm{II}) \mathrm{Pc}$ and $\mathrm{Zn}(\mathrm{II})$ were dialyzed into $1 \mathrm{mM} \mathrm{NaPi}, \mathrm{pH} 6.8$ and concentrated by filtration to $2 \mathrm{mM}$. Unfolded and ApoPc were dialyzed into $300 \mathrm{mM}$ Tris-Cl, $\mathrm{pH} 7,1 \mathrm{M} \mathrm{NaCl}$. To compare spectral differences due to buffer composition, FT IR spectra of Pc variants of $\mathrm{Cu}(\mathrm{I}) \mathrm{Pc}, \mathrm{Cu}(\mathrm{II}) \mathrm{Pc}$, $\mathrm{Co}(\mathrm{II}) \mathrm{Pc}$ and $\mathrm{Zn}$ (II)Pc were also taken in $300 \mathrm{mM}$ Tris-Cl, pH 7, $1 \mathrm{M} \mathrm{NaCl}$ (Table S1). Reduction of $\mathrm{Pc}$ to form $\mathrm{Cu}(\mathrm{I}) \mathrm{Pc}$ was achieved by the addition of four molar equivalents of sodium ascorbate. To prepare the low $\mathrm{pH}$ state, $\mathrm{Cu}(\mathrm{II}) \mathrm{Pc}$ was dialyzed extensively in $1 \mathrm{mM}$ $\mathrm{NaPi}$, pH 4.0 concentrated to $2 \mathrm{mM}$ and then reduced by addition of four equivalents of sodium absorbate. For measurement of $\mathrm{Cu}(\mathrm{II}) \mathrm{Pc}$ at low $\mathrm{pH}$, the sample was treated identically as the reduced species at low $\mathrm{pH}$ with the exception of the addition of sodium absorbate. Cyt $f$ was oxidized by the addition of fifty equivalents of $\mathrm{Co}(\mathrm{phen})_{3}{ }^{3+}$. Samples of the Pc-cyt $f$ complex contained $1 \mathrm{mM}$ and $2.26 \mathrm{mM} \mathrm{Pc}$ and cyt $f$, respectively. Measurements of the Pc-cyt $f$ complexes were taken in $1 \mathrm{mM} \mathrm{NaPi}, \mathrm{pH}$ 6.8. For FT IR spectroscopy, the samples were sealed between two $\mathrm{CaF}_{2}$ windows separated by $38.1 \mu \mathrm{m}$ Teflon spacer. 
Table S1. FT IR data of Pc variants in $300 \mathrm{mM}$ Tris-Cl, pH 7, $1 \mathrm{M} \mathrm{NaCl}$ buffer. Data for ApoPc was obtained in buffer containing $500 \mathrm{mM} \mathrm{NaCl}$.

\begin{tabular}{lcc} 
& $v\left(\mathrm{~cm}^{-1}\right)$ & fwhm $\left(\mathrm{cm}^{-1}\right)$ \\
\hline $\mathbf{C u}($ I)Pc & $2123.4 \pm 0.03$ & $7.5 \pm 0.2$ \\
Cu(II)Pc & $2126.1 \pm 0.09$ & $7.8 \pm 0.2$ \\
$\mathbf{Z n}($ II)Pc & $2127.6 \pm 0.06$ & $9.6 \pm 0.4$ \\
Co(II)Pc & $2128.6 \pm 0.16$ & $9.6 \pm 0.4$ \\
Cu(II)Pc, pH 4 & $2126.7 \pm 0.05$ & $8.5 \pm 0.3$ \\
Co-Cu(II)Pc & $2125.9 \pm 0.11$ & $7.7 \pm 0.4$ \\
ApoPc, 500mM NaCl & $2124.5 \pm 0.91(22 \%)$ & $8.5 \pm 1.0$ \\
& $2132.3 \pm 0.68(78 \%)$ & $12.2 \pm 1.7$ \\
\hline
\end{tabular}

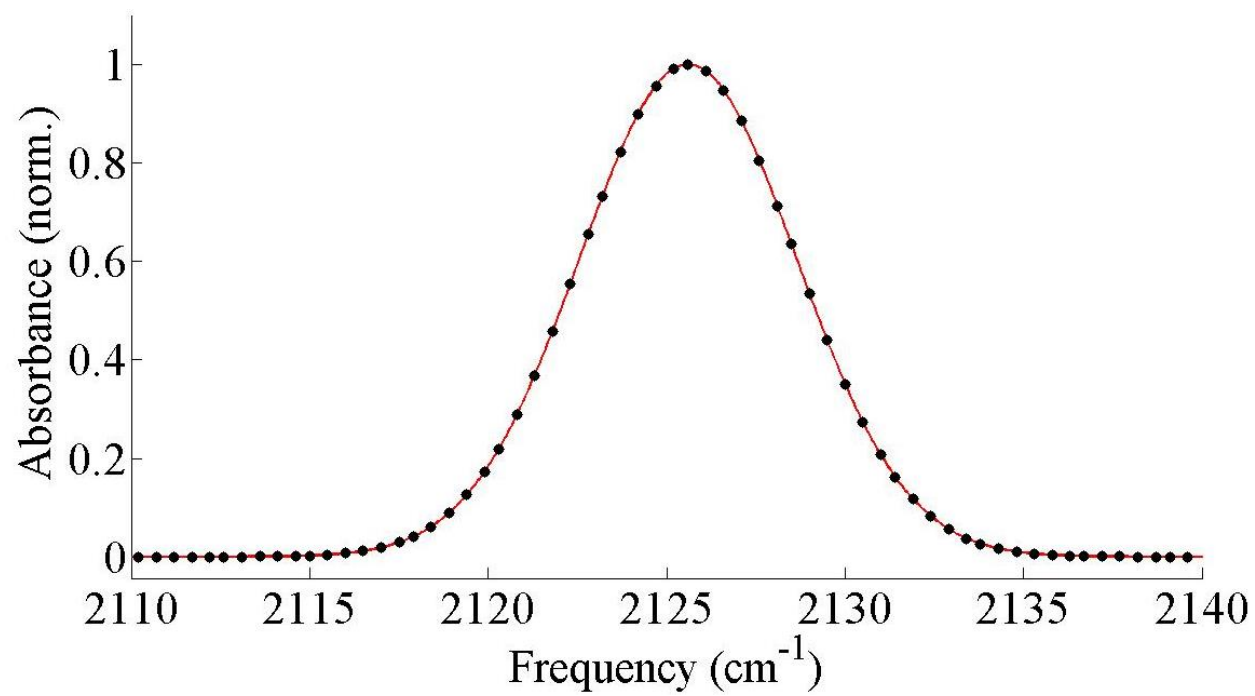

Figure S5. Representative FT IR spectrum of $d_{3} \mathrm{Met} 97 \mathrm{Pc}$ showing the $\mathrm{CD}_{3}$ symmetric stretching absorption (black dots) and fit to a single Gaussian (red line). 


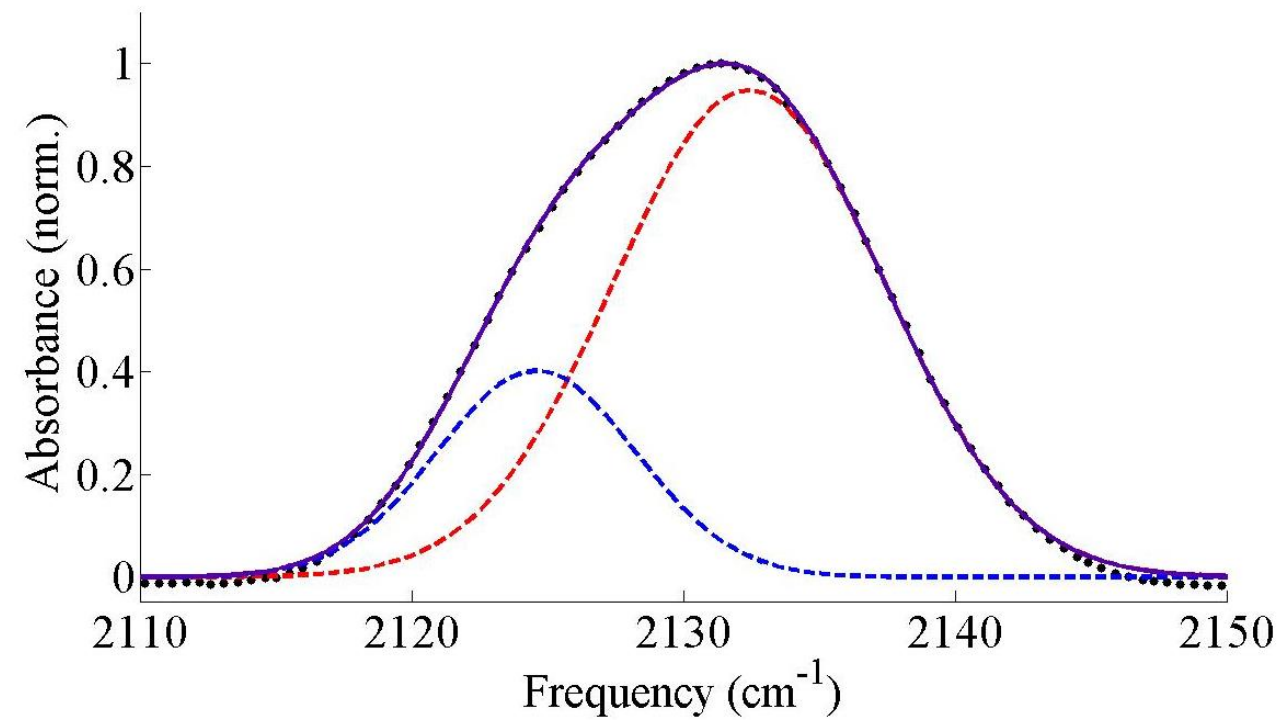

Figure S6. FT IR of ApoPc in $300 \mathrm{mM}$ Tris-Cl, $\mathrm{pH} 7,500 \mathrm{mM} \mathrm{NaCl}$, pH 7. Gaussian components to data are shown in blue and red dashed lines. See Table S1 for frequency and line width values of Gaussian components.

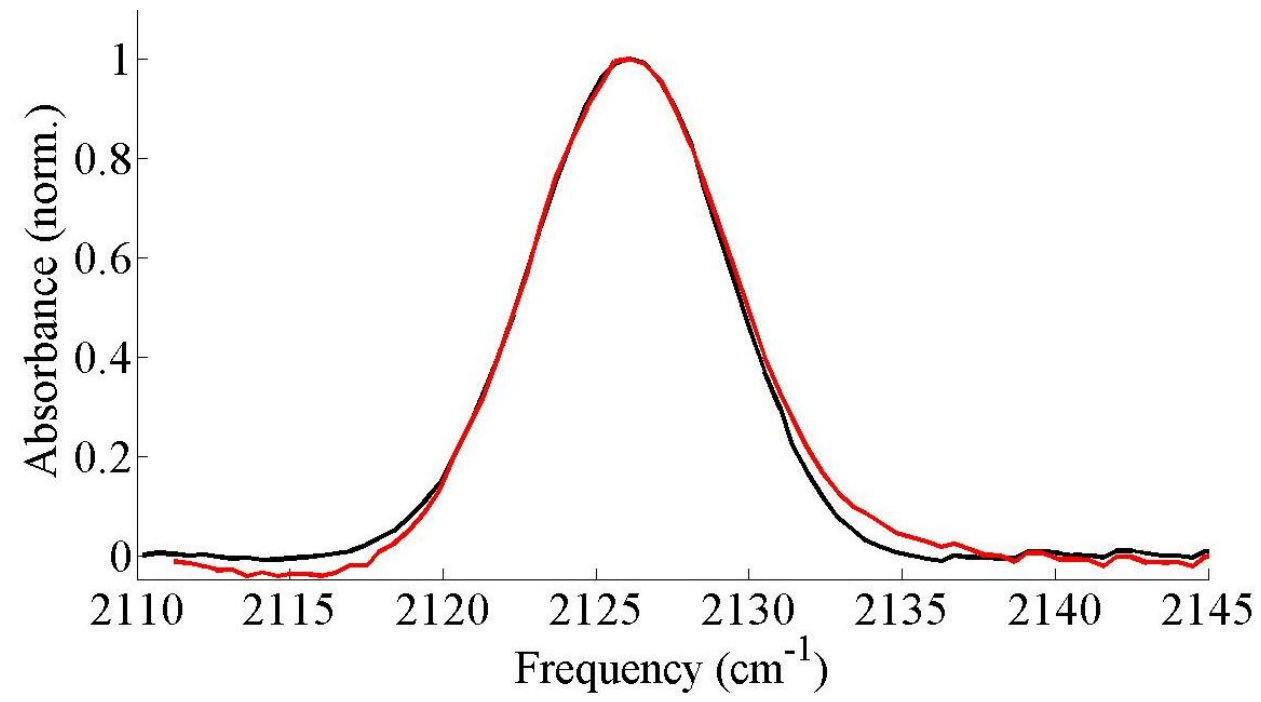

Figure S7. FT IR spectra of $\mathrm{Cu}(\mathrm{II}) \mathrm{Pc}$ (red) and $\mathrm{Cu}$ (II)Pc reconstituted from $\mathrm{Co}$ (II)Pc (black) showing spectral similarity. 


\section{Calculations.}

A
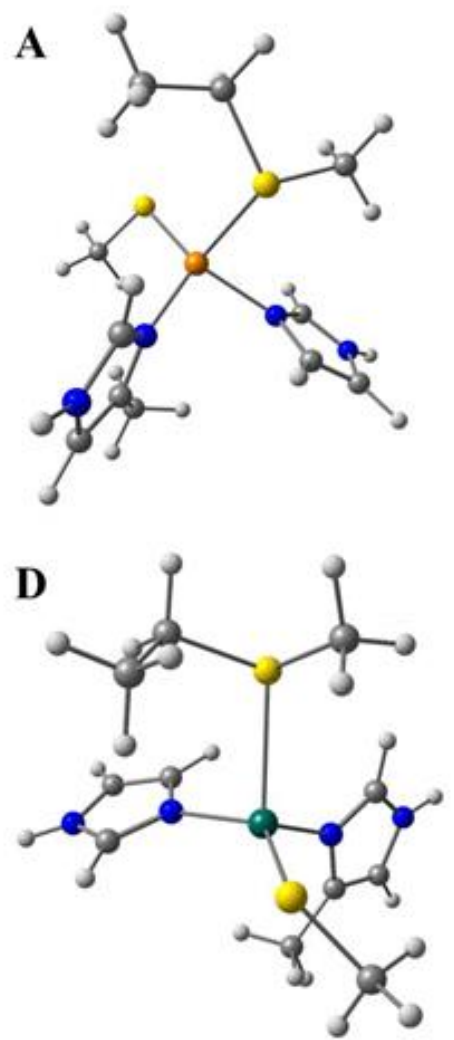

B

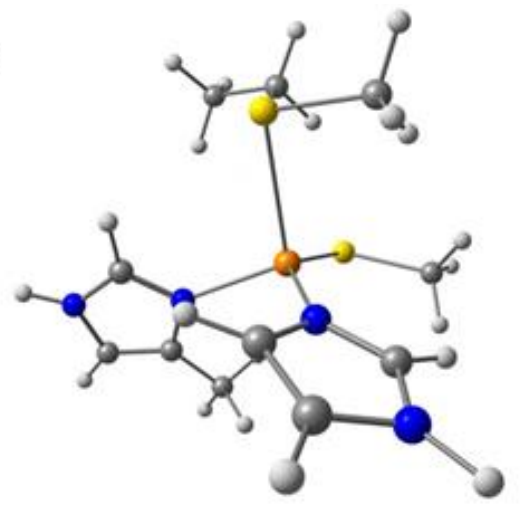

$\mathbf{E}$

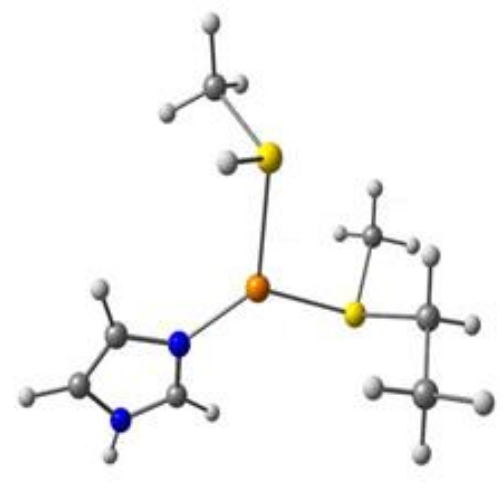

C

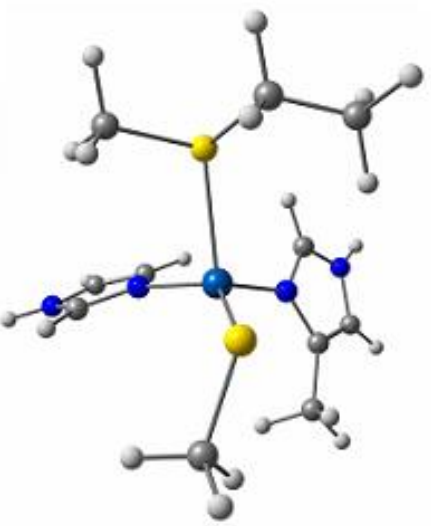

Figure S8. Optimized geometries for (a) oxidized, (b) reduced, (c) Co(II)-substituted, (d) Zn(II)substituted, and (e) reduced $\mathrm{pH} 4$ states, from calculations.

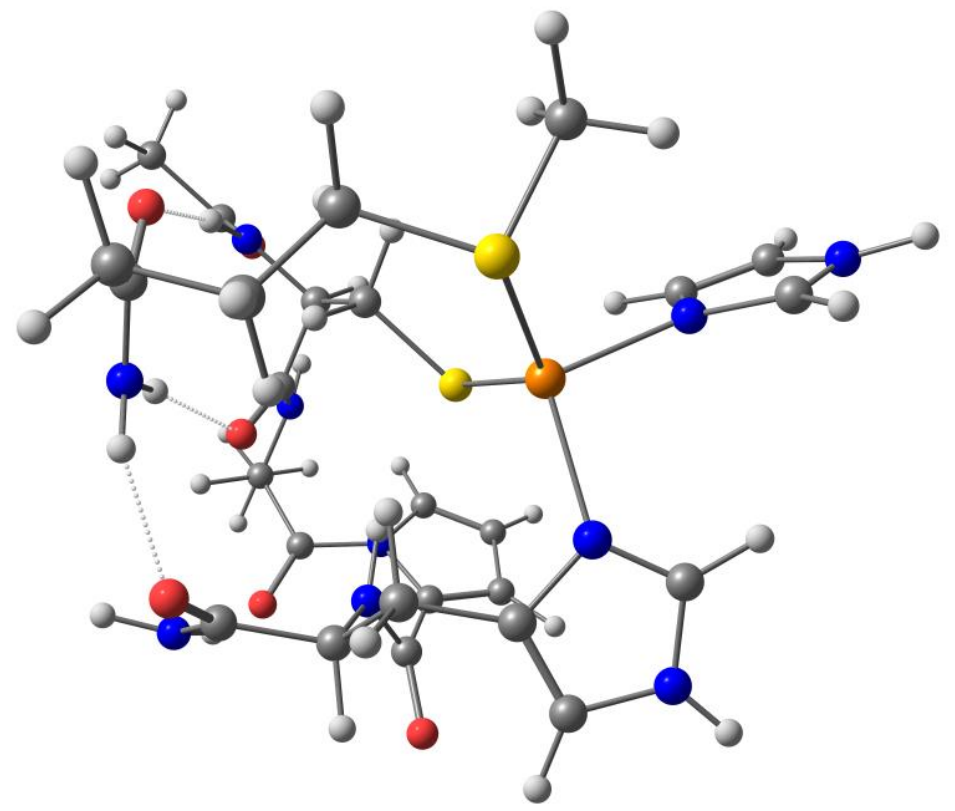

Figure S9. Optimized geometry for the $\mathrm{Cu}(\mathrm{I})$ version of the expanded Pc small model 
Table S2. Comparison of computational results from minimal and medium sized protein structures and different functions.

\begin{tabular}{|c|c|c|c|c|c|c|c|c|}
\hline & \multicolumn{4}{|c|}{ Minimal model } & \multicolumn{4}{|c|}{ Medium sized model } \\
\hline & \multicolumn{2}{|c|}{ B3LYP } & \multicolumn{2}{|c|}{ PBE0 } & \multicolumn{2}{|c|}{ B3LYP } & \multicolumn{2}{|c|}{ PBE0 } \\
\hline & $v\left(\mathrm{~cm}^{-1}\right)$ & $\begin{array}{c}\text { Bond } \\
\text { length }(\AA)\end{array}$ & $v\left(\mathrm{~cm}^{-1}\right)$ & $\begin{array}{c}\text { Bond } \\
\text { length }(\AA)\end{array}$ & $v\left(\mathrm{~cm}^{-1}\right)$ & $\begin{array}{c}\text { Bond } \\
\text { length }(\AA)\end{array}$ & $v\left(\mathrm{~cm}^{-1}\right)$ & $\begin{array}{c}\text { Bond } \\
\text { length }(\AA)\end{array}$ \\
\hline $\mathbf{C u}(\mathbf{I})$ & 2104.9 & $\begin{array}{l}\text { Met-2.70, } \\
\text { Cys-2.25 }\end{array}$ & 2184.2 & $\begin{array}{c}\text { Met-2.65, } \\
\text { Cys-2.22 }\end{array}$ & 2176.6 & $\begin{array}{c}\text { Met-2.50, } \\
\text { Cys-2.34 }\end{array}$ & 2195.4 & $\begin{array}{c}\text { Met-2.39, } \\
\text { Cys-2.32 }\end{array}$ \\
\hline $\mathrm{Cu}(\mathrm{II})$ & 2115.9 & $\begin{array}{c}\text { Met-2.60, } \\
\text { Cys-2.19 }\end{array}$ & 2199.7 & $\begin{array}{c}\text { Met-2.51, } \\
\text { Cys-2.17 }\end{array}$ & 2182.1 & $\begin{array}{c}\text { Met-2.61, } \\
\text { Cys-2.22 }\end{array}$ & 2200.1 & $\begin{array}{c}\text { Met-2.50, } \\
\text { Cys-2.20 }\end{array}$ \\
\hline $\mathrm{Zn}(\mathrm{II})$ & 2116.3 & $\begin{array}{l}\text { Met-2.59, } \\
\text { Cys-2.23 }\end{array}$ & 2199.4 & $\begin{array}{l}\text { Met-2.59, } \\
\text { Cys-2.23 }\end{array}$ & 2186.7 & $\begin{array}{l}\text { Met-2.56, } \\
\text { Cys-2.27 }\end{array}$ & 2204.4 & $\begin{array}{l}\text { Met-2.51, } \\
\text { Cys-2.25 }\end{array}$ \\
\hline $\operatorname{Co}(\mathrm{II})$ & 2117.5 & $\begin{array}{l}\text { Met-2.48, } \\
\text { Cys-2.21 }\end{array}$ & 2200.0 & $\begin{array}{c}\text { Met-2.44, } \\
\text { Cys-2.21 }\end{array}$ & 2184.9 & $\begin{array}{l}\text { Met-2.49, } \\
\text { Cys-2.25 }\end{array}$ & 2201.8 & $\begin{array}{c}\text { Met-2.46, } \\
\text { Cys-2.24 }\end{array}$ \\
\hline $\begin{array}{l}\mathrm{Cu}(\mathrm{I}), \\
\text { pH } 4\end{array}$ & 2116.9 & $\begin{array}{c}\text { Met-2.49, } \\
\text { Cys-2.28 }\end{array}$ & 2200.1 & $\begin{array}{l}\text { Met-2.43, } \\
\text { Cys-2.25 }\end{array}$ & 2185.2 & $\begin{array}{c}\text { Met-2.30, } \\
\text { Cys-2.41 }\end{array}$ & N.A. & N.A. \\
\hline
\end{tabular}

To better study the effects of varying positive charge at sulfur on the methyl C-D symmetric stretch of ethyl methyl sulfide- $\mathrm{d}_{3}$, a small model was constructed consisting of ethyl methyl sulfide and a point charge of varying magnitude positioned 2.0 $\AA$ from $\mathrm{S}$ on a vector orthogonal to the C-S-C plane. Unlike the rest of the study these calculations were carried out using Jaguar $8.1^{10}$ since it supports optimization and frequency calculations in the presence of a point charge. As the magnitude of the point charge was increased, the frequency of the symmetric C-D stretching mode increased and the average C-D distance decreased subtly but consistently (Table S3). It is generally expected that having a positive charge interact with a molecule will lead to a reduction of electron density of the species and a weakening of bonds on that species which necessarily leads to lower frequency ground state vibrational modes. In this case, the positive charge interacting with $\mathrm{S}$ increases the strength of the C-D bonds of the neighboring methyl group. Application of MO theory to this problem provides an explanation of this effect.

Table S3. Comparison of C-D stretching modes and C-D bond distances for ethyl methyl sulfide$d_{3}$ under the influence of point charges of varying magnitudes

\begin{tabular}{ccc}
\hline $\begin{array}{c}\text { Point charge magnitude } \\
\text { (a.u.) }\end{array}$ & $\begin{array}{c}\text { Avg. C-D distance for S } \\
\text { bound Met }(\mathbf{A})\end{array}$ & $\begin{array}{c}\text { Calculated C-D symmetric } \\
\text { stretching mode }\left(\mathbf{c m}^{-1}\right)\end{array}$ \\
\hline 0.00 & 1.0942 & 2093.3 \\
0.25 & 1.0936 & 2099.7 \\
0.50 & 1.0930 & 2105.5 \\
0.75 & 1.0929 & 2109.3 \\
1.00 & 1.0922 & 2111.8 \\
\hline
\end{tabular}

The strength of the interaction between two orbitals depends on three things: spatial overlap, symmetry, and energy difference. Therefore, if two orbitals have compatible symmetry then the strength of their interaction will depend on overlap and energy difference. In this case the $\mathrm{S} \mathrm{p}$ orbitals have the correct symmetry to interact with both the C-H/D $\sigma$ and $\sigma^{*}$ orbitals, with the 
result being three orbitals with varying amounts of $\mathrm{S} \mathrm{p}, \mathrm{C}-\mathrm{H} / \mathrm{D} \sigma$ and $\mathrm{C}-\mathrm{H} / \mathrm{D} \sigma^{*}$ character (Figure S11). If we assume that the C-H/D $\sigma$ and $\sigma^{*}$ orbitals have similar spatial overlap with the $\mathrm{S} \pi$ space then the main factor determining the extent to which these orbitals interact is the energy differences between them. At the B3LYP cc-pVDZ level of theory, the HOMO of ethyl methyl sulfide is almost entirely $\mathrm{S} p$ in character but takes on increasing C-H/D $\sigma$ character as the magnitude of the point charge is increased (Figure S10). This is consistent with the point charge lowering the energy of the S p orbital, allowing for increased interaction with the C-H/D $\sigma$ orbitals, and reducing the C-H/D $\sigma^{*}$ character (Figure S11). Thus, the experimentally observed shift in C-D stretching frequency is best described as an effect stemming from perturbation of the S-C interaction.
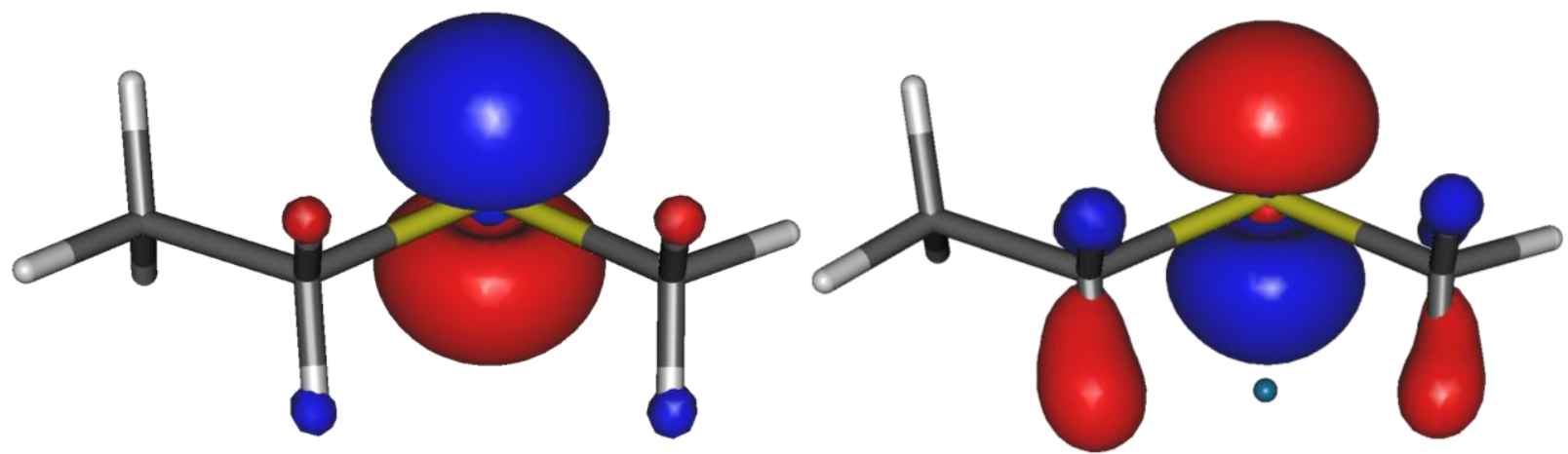

Figure S10: HOMO of methyl ethyl sulfide in the absence (left) and presence (right) of a point charge of 1.00 a.u. (isosurface value 0.08 a.u.)
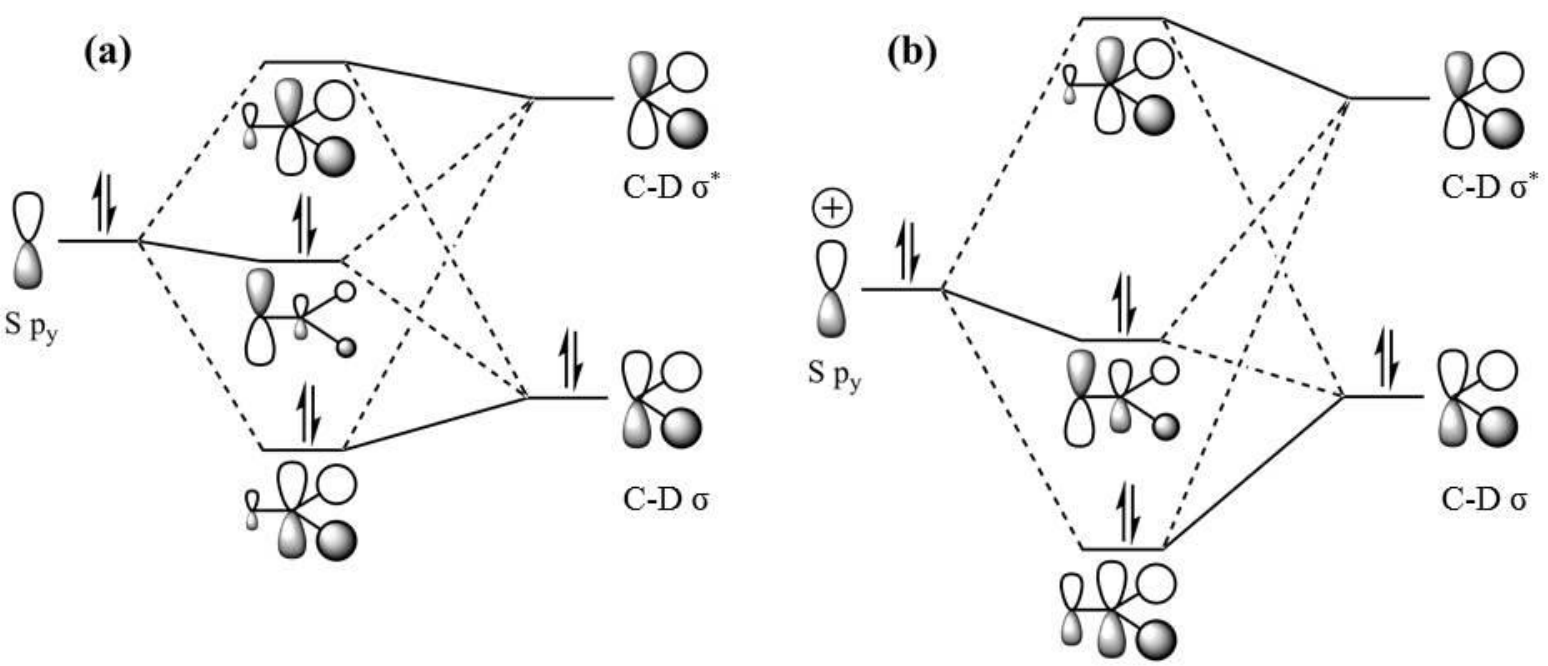

Figure S11: Schematic molecular orbital diagram for interaction of C-D orbitals with the methionine sulfur in the (a) absence and (b) presence of a positively charged $\mathrm{Cu}$ center. 


\section{References.}

(1) Molina-Heredia, F. P.; Hervas, M.; Navarro, J. A.; De la Rosa, M. A. Biochem. Biophys. Res. Commun. 1998, 243, 302

(2) Diaz-Moreno, I.; Diaz-Quintana, A.; De la Rosa, M. A.; Crowley, P. B.; Ubbink, M. Biochemistry 2005, 44, 3176

(3) Liao, Y.-D.; Jeng, J.-C.; Wang, C.-F.; Wang, S.-C.; Chang, S.-T. Protein Sci. 2004, 13, 1802

(4) Solomon, E. I.; Hare, J. W.; Gray, H. B. Proc. Natl. Acad. Sci. U. S. A. 1976, 73, 1389

(5) Koide, S.; Dyson, H. J.; Wright, P. E. Biochemistry 1993, 32, 12299

(6) McMillin, D. R.; Rosenberg, R. C.; Gray, H. B. Proc. Natl. Acad. Sci. U. S. A. 1974, 71, 4760

(7) Scanu, S.; Forster, J.; Finiguerra, M. G.; Shabestari, M. H.; Huber, M.; Ubbink, M. ChemBioChem. 2012, 13, 1312

(8) Arslan, E.; Schulz, H.; Zufferey, R.; Kunzler, P.; Thony-Meyer, L. Biochem. Biophys. Res. Commun. 1998, 251, 744

(9) Albarran, C.; Navarro, J. A.; Molina-Heredia, F. P.; Murdoch, P. d. S.; De la Rosa, M. A.; Hervas, M. Biochemistry 2005, 44, 11601

(10) Jaguar, version 8.1, Schrodinger, LLC: New York, NY (2013) 